\title{
On the origin and properties of scent marks deposited at the food source by a stingless bee, Melipona seminigra
}

\author{
Michael HRNCIR $^{\text {a* }}$, Stefan JARAU ${ }^{\mathrm{a}}$, Ronaldo ZUCCHI ${ }^{\mathrm{b}}$, Friedrich G. BARTH ${ }^{\mathrm{a}}$ \\ a University of Vienna, Biocenter, Institute of Zoology, Althanstr.14, 1090 Wien, Austria \\ b University of São Paulo, FFCLRP, Department of Biology, Avenida Bandeirantes 3900, 14040-901 Ribeirão \\ Preto, SP, Brasil
}

(Received 7 January 2003; revised 9 April 2003; accepted 11 June 2003)

\begin{abstract}
Some species of stingless bees of the genus Melipona were reported to scent mark food sources but little is known about the chemical signals involved. We studied the origin and some properties of such scent marks in M. seminigra. Results from choice experiments suggested that the bees do not scent mark the food (sugar water) itself and that abdominal droplets were excluded as the signal source. Extracts of the most distal tarsomeres, however, attracted recruits in the same way as natural scent marks. We conclude that M. seminigra scent marks a food source by leaving "footprints" secreted at the leg tips. The footprints of at least 40 visits were needed to effectively scent mark. The chemical signal has an active range of about $1 \mathrm{~m}$ and its effect persists for about 2 hours. In the absence of footprints no scent marking effect was seen. This finding excludes the importance of mandibular gland secretions (if at all present) for the scent marking observed.
\end{abstract}

stingless bee / Melipona / scent marking / footprint substance / recruitment

\section{INTRODUCTION}

In social bees scent marking of a food source is a common phenomenon and is well studied in both honeybees and bumblebees (honeybees: Nuñez, 1967; Ferguson and Free, 1979; Free and Williams, 1983; Corbet et al., 1984; Giurfa and Nuñez, 1992; Giurfa, 1993; Williams, 1998; bumblebees: Cameron, 1981; Schmitt and Bertsch, 1990; Goulson et al., 1998; Stout et al., 1998; Stout and Goulson, 2001). Scent marks increase the foraging efficiency of the bees (Weatherwax, 1986; Kato, 1988; Schmitt and Bertsch, 1990; Giurfa and Nuñez, 1992). The scent marks are either attractant, marking rich food sources to decrease the search time, or they are repellent, helping the bees to avoid recently depleted flowers (attractants: Ferguson and Free, 1979; Cameron, 1981; Free and Williams, 1983;
Schmitt and Bertsch, 1990; repellents: Nuñez, 1967; Corbet et al., 1984; Giurfa and Nuñez, 1992; Giurfa, 1993; Williams, 1998; Stout et al., 1998; Goulson et al., 1998; Stout and Goulson, 2001). Secretions from the Nasanov glands, the sting apparatus, the mandibular glands, and the tarsal glands have been proposed to be the source of these scent marks (Free et al., 1982; Winston, 1987; Schmitt et al., 1991; Vallet et al. 1991; Free and Williams, 1993; Giurfa, 1993; Goulson et al., 2000; Stout and Goulson, 2001).

Among the stingless bees, several species use chemical signals to communicate the location of a food source to nestmates by laying a scent trail from the food source to their nest (Lindauer and Kerr, 1958; Kerr et al., 1963; Kerr and Esch, 1965; Kerr et al., 1981; Schmidt et al., 2003). Like honeybees and bumblebees, some species scent mark the food 
source itself (Villa and Weiss, 1990; Nieh, 1998; Aguilar and Sommeijer, 2001; Goulson et al., 2001; Schmidt et al., 2003). Again, the scent marks are either attractant (Trigona angustula, T. peckolti, and T. mexicana: Villa and Weiss, 1990; Scaptotrigona aff. depilis: Schmidt et al., 2003) or repellent (T. fulviventris: Goulson et al., 2001). Bees of the genus Melipona Illiger do not use scent trails to guide recruits to a food source (Lindauer and Kerr, 1958; Nieh and Roubik, 1995; Hrncir et al., 2000). However, they do deposit scent marks near or at the food source (Kerr and Rocha, 1988; Kerr, 1994; Nieh, 1998; Aguilar and Sommeijer, 1996, 2001) which attract newcomers (Nieh, 1998; Aguilar and Sommeijer, 2001). Knowledge of the properties of such scent marks is very scarce (Nieh, 1998) and studies on their origin are controversial: for M. panamica scent marks deposited by foragers were proposed to be a "hive odor" rather than a specific pheromone because mandibular gland extracts and anal droplets were not involved in scent marking (Nieh, 1998). In $M$. favosa, on the other hand, scent marks were proposed to be derived from the anal droplets deposited at and near the food source (Aguilar and Sommeijer, 1996, 2001).

In a preliminary study, attractive scent marks at the food source were described for M. seminigra (Jarau et al., 2002). In the present study we ask four questions. (1) Does $M$. seminigra use abdominal droplets, mandibular gland secretions, or "footprints" to scent mark a food source? (2) How many visits are necessary to elicit a response? (3) For how long do the scent marks remain effective? (4) What is their active range?

\section{MATERIALS AND METHODS}

The experiments were carried out on the campus of the University of São Paulo in Ribeirão Preto, Brazil, between December 2000 and July 2001. We used a colony of a hitherto undescribed subspecies of Melipona seminigra Friese 1903 (Camargo, unpublished data). Experiments were performed between $1000 \mathrm{~h}$ and $1600 \mathrm{~h}$ with the setups mounted on tables (height: $75 \mathrm{~cm}$ ), 20 meters to the northwest of the hive. The feeders were small round plastic cups on plastic discs (Fig. 1A). Tables and feeders were cleaned using ethanol (95\% vol.). When training the bees to the experimental site and
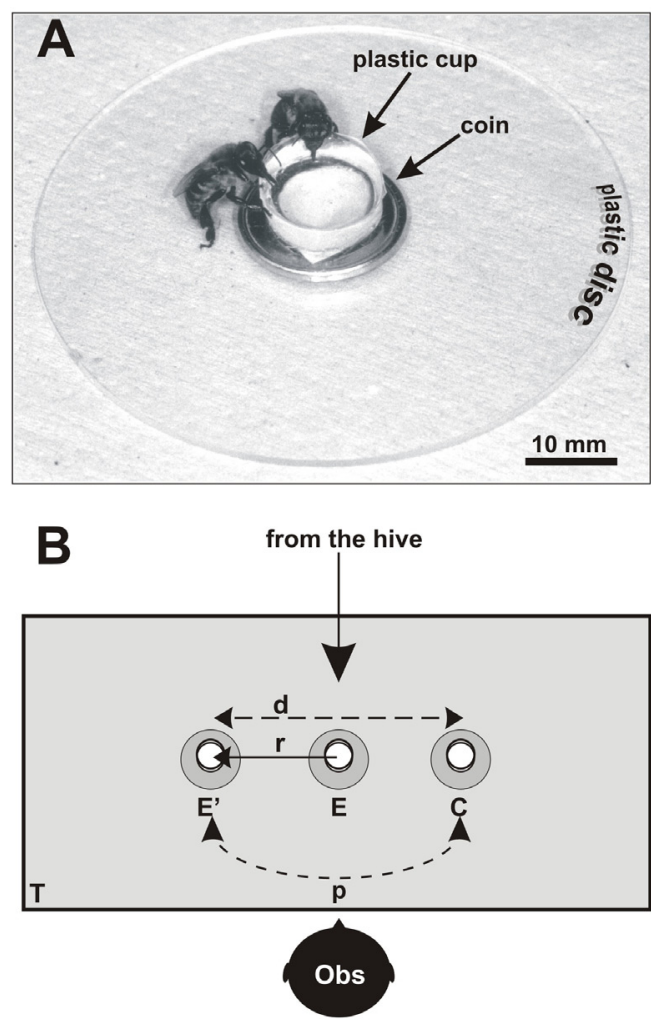

Figure 1. Setup. (A) Feeders. Plastic cups (diameter: $15 \mathrm{~mm}$; depth: $5 \mathrm{~mm}$ ) were glued onto a coin (1 Centavo; diameter: $17 \mathrm{~mm}$ ) to prevent the bees from turning it over. The cups together with the coin rested on a plastic disc (diameter: $65 \mathrm{~mm}$ ). (B) Choice test. The setups rested on a table $(T)$. After the scent marking phase the experimental feeder $(E$ ') was moved by distance $r$ to the right or to the left of its original position $(E)$. Note control feeder $(C)$ on the opposite side and at the same distance $r$ from $E(d=2 r)$. Obs, observer.

for the choice experiments we used sugar water $(1.5 \mathrm{M})$ which in most cases was not scented by us. For some experiments (as indicated in the text) we added rosewood essence (Aniba rosaeodora, $\left.0.1 \mathrm{~mL} \mathrm{~L}^{-1}\right)$.

\subsection{Choice tests}

In choice tests (Fig. 1B) the bees had to distinguish a "used" feeder (where other bees had previously collected) from a clean control feeder. (i) Training phase. We trained bees to the experimental site using training feeders (Jarau et al., 2000) which contained food of the same quality (i.e. 
Table I. Choice tests on the origin of the scent marks. As possible sources of scent marks at the food source we studied sugar water on which foragers had fed ("used" sugar water), abdominal droplets deposited by foragers at the food source, and footprints left by foragers. In addition, the effects of cuticular hydrocarbons (leg cuticle) and glandular substances within the tarsi (extract of tarsomeres) on the choice behavior of the bees were tested. See text for details. The bees had to choose between a feeder baited with the potential scent mark (feeder 1) and a control feeder (feeder 2). Both feeders contained unscented sugar water and their distance from each other was $20 \mathrm{~cm}$. N, number of bees; n, number of choices.

\begin{tabular}{|c|c|c|c|c|}
\hline & \multicolumn{4}{|c|}{ Choice phase } \\
\hline & Feeder 1 & Feeder 2 & $\begin{array}{c}\text { Number of } \\
\text { experiments }\end{array}$ & $\mathbf{N}(\mathbf{n})$ \\
\hline sugar water & $\begin{array}{l}\text { "used" sugar water } \\
\text { (after } 40 \text { visits) }\end{array}$ & fresh sugar water & 6 & $148(148)$ \\
\hline \multirow{3}{*}{$\begin{array}{l}\text { abdominal } \\
\text { droplets }\end{array}$} & droplets & no droplets & 6 & $133(133)$ \\
\hline & droplets & "used" cup, no droplets & 6 & $113(113)$ \\
\hline & bee's own droplets & no droplets & 6 & $6(60)$ \\
\hline \multirow{3}{*}{$\begin{array}{c}\text { footprint } \\
\text { substances }\end{array}$} & $\begin{array}{c}\text { visited } 40 \text { times } \\
\text { (tarsi and pretarsi covered) }\end{array}$ & clean & 4 & $80(80)$ \\
\hline & $\begin{array}{l}\text { visited } 80 \text { times } \\
\text { (tarsi and pretarsi covered) }\end{array}$ & clean & 4 & $80(80)$ \\
\hline & $\begin{array}{l}\text { visited } 40 \text { times } \\
\text { (femora covered) }\end{array}$ & clean & 4 & $100(100)$ \\
\hline \multirow{3}{*}{$\begin{array}{l}\text { pentane } \\
\text { extracts }\end{array}$} & $\begin{array}{l}30 \mu \mathrm{L} \text { pentane extract } \\
\text { leg cuticle }(90 \text { legs })\end{array}$ & $30 \mu \mathrm{L}$ pentane & 6 & $128(128)$ \\
\hline & $\begin{array}{l}30 \mu \mathrm{L} \text { pentane extract } \\
\text { tarsomeres }(30 \text { legs })\end{array}$ & $30 \mu \mathrm{L}$ pentane & 6 & 187 (187) \\
\hline & $\begin{array}{l}30 \mu \mathrm{L} \text { pentane extract } \\
\text { tarsomeres }(60 \text { legs })\end{array}$ & $30 \mu \mathrm{L}$ pentane & 6 & $86(86)$ \\
\hline
\end{tabular}

scented or unscented sugar water) as later used for the choice experiments. The bees were allowed to collect for about half an hour before they were captured. (ii) Scent marking phase. A small number (depending on the experiment) of the bees captured at the end of the training phase (henceforth called foragers) was marked with color dots and released. The training feeder was replaced by an experimental feeder (Fig. 1A) at the identical position. After a certain number of visits (depending on the experiment) the foragers were re-captured and kept separate. (iii) Choice phase. The position of the experimental feeder was now shifted either to the left or right of its original position by distance $r$. On the opposite side, at the same distance $r(2 \mathrm{r}=\mathrm{d})$, an identical control feeder (not previously visited) offered sugar water of the same quality. Now the bees captured at the end of the training phase (except those used for scent marking) were released in front of the hive entrance. The bees had to choose between the scent marked experimental feeder and the control feeder. All bees could choose only once and were captured immediately after landing at either of the two feeders. Only the bees landing while no other bees were at or near the feeders were counted in order to avoid the effects of visual or other unwanted signals provided by such bees. To eliminate site bias caused by possible differences due, e.g., to illumination or wind we exchanged the feeders' positions every 5 minutes. The choice phase lasted for 20 minutes.

\subsection{Origin of scent marks}

Sugar water. After a forager had fed on a feeder 40 times the remaining sugar water was removed using an alcohol cleaned syringe and was filled into a fresh alcohol cleaned feeder (for the performed choice test see Tab. I).

Abdominal droplets. Abdominal droplets were collected while 10 foragers fed at a feeder for about half an hour. For this purpose the plastic disc of the feeder was covered by nylon netting (held by a circular frame, diameter $6.5 \mathrm{~cm}$, height $1.5 \mathrm{~cm}$ ) to prevent the bees from touching the disc. Abdominal droplets deposited by foragers fell through the netting and could be collected on the plastic disc 
without mixing them with potentially existing "footprint substances". The effect of the collected abdominal droplets $(126.8 \pm 32.7$ droplets; 12 experiments) on the choice behavior of the bees was studied in three experimental series (Tab. I).

Footprint substances. We covered 3 or 4 of the most distal tarsal segments of all legs of 4 foragers with nail polish before they visited a clean feeder 40 or 80 times, respectively. In control experiments on the influence of the nail polish itself, the femora of 4 foragers were covered with nail polish (40 visits) (Tab. I).

Cuticle and tarsal extracts. We determined whether "footprints" are secreted at the bees' feet (pretarsi) or substances on the legs' general cuticle serve as scent marks. 15 foragers were sacrificed individually by freezing. Substances on the legs' surface and cuticular hydrocarbons were extracted from the legs by placing them into $1.0 \mathrm{~mL}$ of pentane for 30 seconds (Golub and Weatherston, 1984; Ayasse et al., 1999). The last tarsal segments of 30 and 60 legs, respectively, were then cut off and put into $0.3 \mathrm{~mL}$ of pentane for 24 hours to extract glandular substances (Golub and Weatherson, 1984; Ayasse et al., 1999). With the 3 different extracts (leg cuticle, 30 tarsomeres, 60 tarsomeres) choice tests were performed (Tab. I).

\subsection{Properties of scent marks}

To determine the properties of the scent marks deposited by $M$. seminigra foragers at the food source, four parameters were varied in the choice tests (Tab. II): (i) distance $d$ between experimental feeder and control feeder, (ii) number of foragers, (iii) number of forager visits, and (iv) quality of the food (scented or unscented). The persistence of scent marks was studied by first storing away the experimental feeder for various periods of time (at ambient temperature inside the laboratory) (Tab. II) and then reusing it.

\subsection{Statistical analysis}

Control Group. For each tested distance $d$ between feeder and control feeder (Tab. II) recruits had to choose between two identical feeders (both alcohol cleaned) containing unscented sugar water in 6 control experiments.

The number of bees collecting at the feeders varied greatly between December 2000 and July 2001. We therefore calculated the proportional distribution of bees at the feeder and the control feeder for each experiment $(100 \%=$ total number of bees captured at feeder plus control feeder during one test). Student- $t$-Tests, one-way ANOVA (Tukey-HSD comparison) or Kruskal-Wallis tests
(Dunn's pairwise comparison) were used for the statistical comparison (Sokal and Rohlf, 1995). Differences from an equal distribution of the bees at both feeders (distribution in the control test series with two clean feeders) were considered significant at $P \leq 0.05$. All values are given as means $\pm 1 \mathrm{SD}$. N refers to the number of bees, $\mathrm{n}$ to the number of observations/choices.

\section{RESULTS}

\subsection{Feeding behavior}

30 bees $(\mathrm{N}=30)$ were observed when feeding $1.5 \mathrm{M}$ sugar solution at a training feeder ad libitum $(\mathrm{n}=172)$. They spent an average of $22.0 \pm 2.8 \mathrm{~s}$ at the food source for a single visit. The food intake itself took $20.2 \pm 2.0 \mathrm{~s}$. Sometimes the bees showed autogrooming (11.9\% of the observations), abdominal dragging $(0.24 \%)$, deposition of abdominal droplets $(54.7 \%)$, and the production of sounds $(2.87 \%)$ at the food source before or after feeding. The rate at which abdominal droplets were deposited varied considerably among individuals (from $0.3 \pm 0.2$ to $1.2 \pm 0.4$ droplets per visit).

\subsection{Control Group}

Close to $50 \%$ of the bees landed on either of the two identical, alcohol cleaned feeders (Figs. 2-4, dashed horizontal lines representing mean values). As predicted, there were no clues enabling the bees to distinguish between the feeders.

\subsection{Origin of scent marks}

As possible sources of the scent marks we examined the sugar water on which the bees had fed, the abdominal droplets left on the feeder, and footprint substances.

Sugar water. When choosing between "used" and fresh sugar water, there was no difference from the control group (Student- $t$-Test, $\mathrm{T}_{10}=$ 2.02, $P>0.05$ ) (Fig. 2A).

Abdominal droplets. Bees had to choose (i) between a feeder with abdominal droplets and a clean feeder, (ii) between a feeder with abdominal droplets and the plastic cup on which foragers had previously fed (on a clean 
Table II. Choice tests on the properties of the scent marks. During the Scent marking phase the number of foragers and the total number of forager visits varied. During the Choice phase the distance $d$ between experimental feeder and control feeder, and the food quality were varied and either scented $(s)$ or unscented $(u)$ sugar water was used. In some tests preceding the Choice phase (preparation of the test, Prep.) we stored the experimental feeders away at ambient temperature for different periods of time (storing time). The parameters varied in a particular test series are printed in bold letters. $\mathrm{N}$, number of bees (and choices; $\mathrm{N}=\mathrm{n}$ ).

\begin{tabular}{cc|c|cccc}
\hline \multicolumn{2}{c|}{ Scent marking phase } & Prep. & \multicolumn{4}{|c}{ Choice phase } \\
\hline foragers & $\begin{array}{c}\text { total number } \\
\text { of visits }\end{array}$ & $\begin{array}{c}\text { storing time } \\
(\mathrm{min})\end{array}$ & $\begin{array}{c}\text { d } \\
(\mathrm{cm})\end{array}$ & $\begin{array}{c}\text { food } \\
\text { quality }\end{array}$ & $\begin{array}{c}\text { Number of } \\
\text { experiments }\end{array}$ & $\mathbf{N}$ \\
\hline 1 & 40 & -- & $\mathbf{5}$ & $\mathbf{u}$ & 6 & 98 \\
1 & 40 & -- & $\mathbf{2 0}$ & $\mathbf{u}$ & 6 & 63 \\
1 & 40 & -- & $\mathbf{1 0 0}$ & $\mathbf{u}$ & 6 & 111 \\
1 & 40 & -- & $\mathbf{1 5 0}$ & $\mathbf{u}$ & 6 & 89 \\
1 & 40 & -- & $\mathbf{2 0 0}$ & $\mathbf{u}$ & 6 & 70 \\
& & & & & & \\
1 & 40 & -- & $\mathbf{5}$ & s & 6 & 71 \\
1 & 40 & -- & $\mathbf{2 0}$ & s & 6 & 250 \\
1 & 40 & -- & $\mathbf{1 0 0}$ & s & 6 & 143 \\
1 & 40 & -- & $\mathbf{1 5 0}$ & s & 6 & 63 \\
1 & 40 & -- & $\mathbf{2 0 0}$ & s & 6 & 112 \\
\hline 10 & 40 & -- & 20 & s & 6 & 126 \\
\hline $\mathbf{1}$ & $\mathbf{2 0}$ & -- & 20 & u & 6 & 66 \\
$\mathbf{1}$ & $\mathbf{3 0}$ & -- & 20 & u & 6 & 84 \\
$\mathbf{1}$ & $\mathbf{4 0}$ & -- & 20 & u & 6 & 63 \\
$\mathbf{1 0}$ & $\mathbf{1 0 0}$ & -- & 20 & u & 6 & 120 \\
$\mathbf{1 0}$ & $\mathbf{2 0 0}$ & -- & 20 & u & 6 & 104 \\
\hline 10 & mean: & $\mathbf{3 0}$ & 20 & u & 6 & 98 \\
10 & 89.3 & $\mathbf{6 0}$ & 20 & u & 6 & 100 \\
10 & \pm 6.6 & $\mathbf{1 2 0}$ & 20 & u & 6 & 100 \\
10 & & $\mathbf{1 8 0}$ & 20 & u & 6 & 82 \\
10 & $(10$ min $)$ & $\mathbf{2 4 0}$ & 20 & u & 6 & 120 \\
\hline & & & & & & \\
\hline
\end{tabular}

disc without droplets), and (iii) between a feeder baited with their own abdominal droplets and a clean feeder. The results of these three experiments (Fig. 2B) were compared with the control group (one-way ANOVA, $\mathrm{F}_{3,20}=16.14, P<0.001$, Tukey comparison). In test series (i) and (iii), where bees had to choose between a feeder with abdominal droplets and a clean feeder, there was no significant difference from the control group $\left(\mathrm{Q}_{(\mathrm{i} \text {-control })}=0.98, \mathrm{Q}_{(\text {iii-control })}=1.61\right.$, $P>0.05$ ). In test series (ii) the bees were significantly attracted by the cup where other bees had previously collected $\left(\mathrm{Q}_{(\mathrm{ii}-\mathrm{control})}=\right.$ 6.78, $P<0.05)$.

Footprint substances. Bees had to choose between clean feeders and (i) feeders visited 40 times and (ii) feeders visited 80 times by foragers with covered tarsi, and (iii) feeders visited 40 times by foragers with femora painted with nail polish. The results (Fig. 3A) were compared with the control group, and with the experimental group $\mathrm{U} 40 \mathrm{~V}$ (Unscented sugar water, 40 forager Visits of 

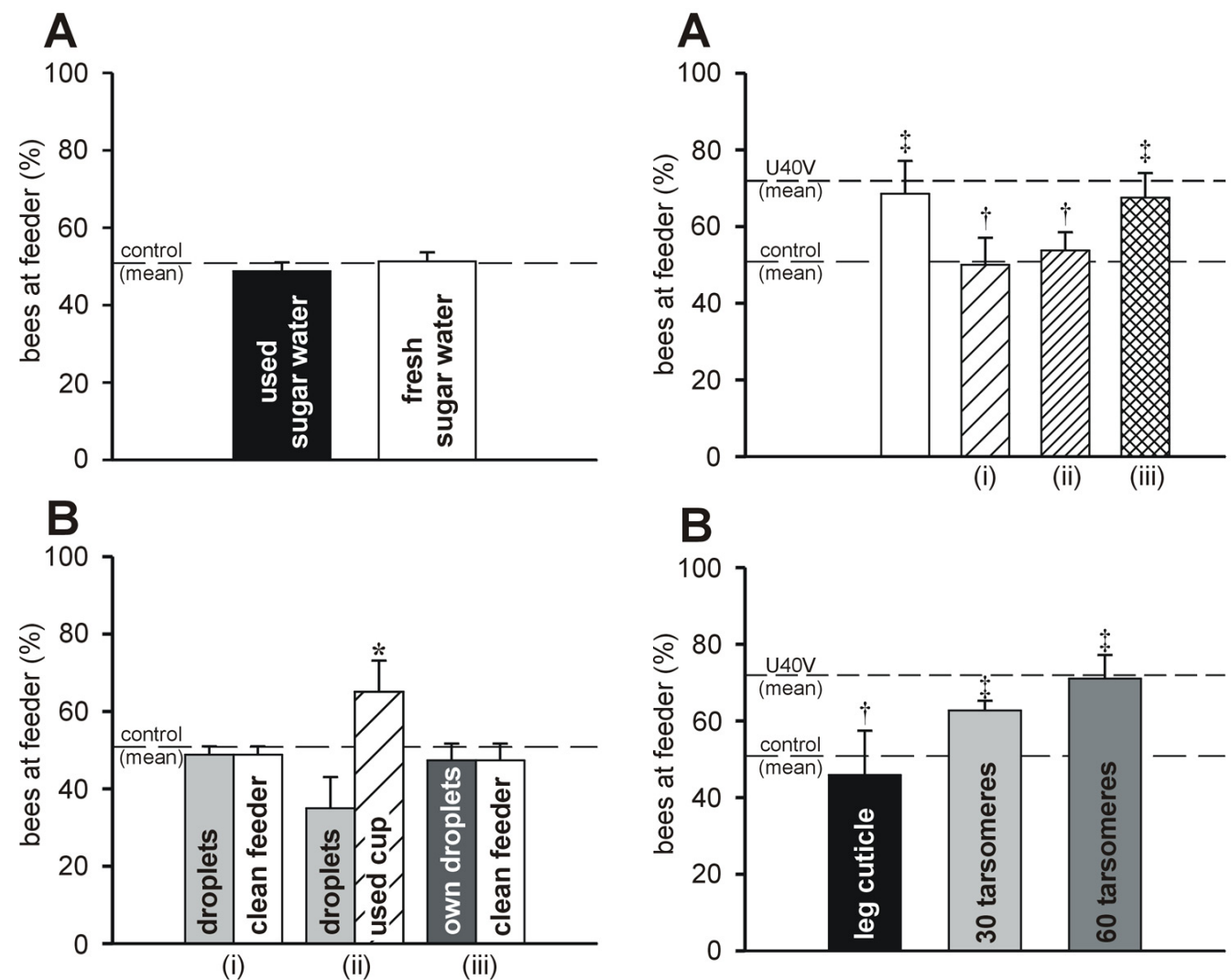

Figure 2. Source of scent marks. Distribution of bees (mean percentage $+1 \mathrm{SD}$ ) at feeders when the choice was (A) between "used" sugar water (black bar) and fresh sugar water (open bar), and (B) between feeders baited with abdominal droplets and control feeders (Tab. I). Asterisk indicates a significant difference to the control group. For details on statistics and experiments see text and Table I.

untreated bees; bees have to choose between a scent marked feeder and a clean control feeder; $\mathrm{d}=20 \mathrm{~cm}$; Fig. 4B) (one-way ANOVA, $\mathrm{F}_{5,30}=10.18, P<0.001$, Tukey comparison). After 40 and 80 visits of foragers with covered tarsi the proportion of bees choosing the experimental feeder did not significantly differ from the control group $\left(\mathrm{Q}_{(40 \text {-control })}=0.26, \mathrm{Q}_{(80 \text {-control })}=0.88, P>\right.$ $0.05)$. After painting the foragers' femora the difference from the experimental group $\mathrm{U} 40 \mathrm{~V}$ was not significant $\left(\mathrm{Q}_{\text {(femora-U40V) }}=\right.$ $1.39, P>0.05)$ whereas to the difference from the control group was significant $\left(\mathrm{Q}_{(\text {femora-control })}=5.03, P<0.05\right)$.

Figure 3. Footprints as scent marks. (A) Open bar: mean percentage (+ 1SD) of bees choosing the experimental feeder after 40 visits by untreated foragers (open bar; 12 experiments, $\mathrm{N}=232, \mathrm{n}=$ 232); (i) bees choosing the feeder after 40 or (ii) 80 visits by foragers with tarsi and pretarsi covered with nailpolish, and (iii) after 40 visits of foragers with their femora covered with nail polish. (B) Bees choosing feeders baited with pentane extracts of leg cuticle, of 30 , and of 60 tarsomeres, respectively. $\neq$, feeders as attractive as a naturally scent marked feeder, no significant difference to experimental series $U 40 \mathrm{~V}$; $\uparrow$, feeders without attracting effect, no significant difference to control group. For details on statistics and experiments see text and Table I.

Cuticle and tarsal extracts. Bees had to choose between feeders baited with pentane extracts of leg cuticle or of bees' tarsi, and feeders baited with pure pentane. Again, the results (Fig. 3B) were compared with the control group, and with the experimental group U40V (one-way ANOVA, $\mathrm{F}_{4,25}=15.13, P<0.001$, Tukey comparison). The proportion of bees choosing the feeder with the cuticle extract was not different from the control 

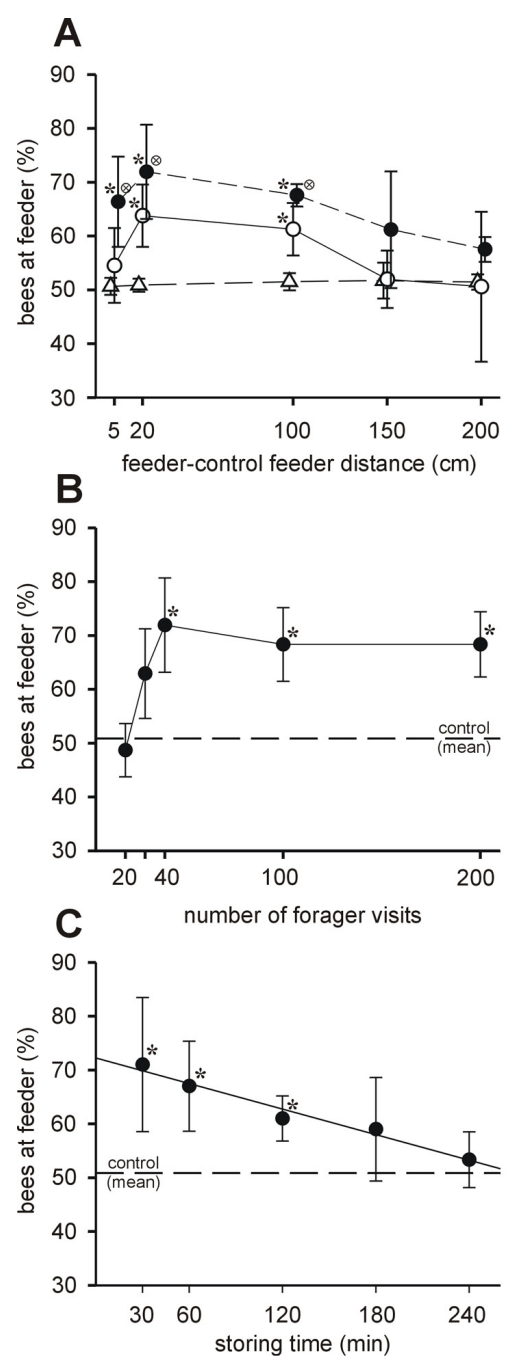

Figure 4. Properties of scent marks. (A) Mean percentage $( \pm$ 1SD) of bees choosing experimental feeders (visited 40 times by foragers), containing scented (open circles) or unscented (filled circles) sugar solution. Data on the more frequently visited feeder in the control experiments are also given (triangles). ${ }^{*}$, significant difference to the control experiment at the respective distance. $\otimes$, significant difference between unscented and scented sugar solution. (B) Bees choosing an experimental feeder after it had been visited 20, 30, 40, 100, and 200 times by foragers. (C) Bees choosing an experimental feeder after it had been stored away for various periods of time. Note decrease of the effect of scent marks with time (linear regression, $\left.\mathrm{R}^{2}=0.40, \mathrm{~b}=-0.08\right) . *$ in $(\mathrm{B})$ and $(\mathrm{C})$, significant difference to the control group $(\mathrm{d}=20 \mathrm{~cm})$. For details on statistics and experiments see text and Table II. group $\left(\mathrm{Q}_{\text {(cuticle-control })}=1.60, P>0.05\right)$. A significantly larger proportion of bees chose the feeders baited with the tarsal extracts, however $\left(\mathrm{Q}_{(30 \text { tarsi-control })}=5.28\right.$, $\left.\mathrm{Q}_{(60 \text { tarsi-control })}=6.45, P<0.05\right)$, and the results of this experiment did not differ significantly from those with experimental group $\mathrm{U} 40 \mathrm{~V}\left(\mathrm{Q}_{(30}\right.$ tarsi-U40V) $=3.09$, $\left.\mathrm{Q}_{(60 \text { tarsi-U40V })}=0.30, P>0.05\right)$.

\subsection{Properties of scent marks}

Active range. After a forager had visited an experimental feeder 40 times a significantly larger proportion of bees alighted at this feeder in the choice phase at feeder - control feeder distances of $5 \mathrm{~cm}$ (Kruskal-Wallis, $\mathrm{H}_{2}=10.98$, $P<0.05$; Dunn's comparison: $\mathrm{Q}_{(\text {scented-control) }}=$ $1.01, P>0.05, \mathrm{Q}_{\text {(unscented-control) }}=3.04, P<$ 0.05 ), $20 \mathrm{~cm}$ (one-way ANOVA, $\mathrm{F}_{2,15}=$ $32.90, P<0.001$ ), and $100 \mathrm{~cm}$ (one-way ANOVA, $\left.\mathrm{F}_{2.15}=11.89, P<0.005\right)$, respectively. At still larger distances no difference could be observed (Kruskal-Wallis, $150 \mathrm{~cm}$ : $\mathrm{H}_{2}=5.52, P>0.05 ; 200 \mathrm{~cm}: \mathrm{H}_{2}=4.51, P>$ $0.05)$. Furthermore, a larger proportion of bees alighted on the experimental feeder when its sugar water was unscented than when it was scented at feeder - control feeder distances of $5 \mathrm{~cm}\left(\mathrm{Q}_{\text {(Dunn's comparison) }}=4.71, P<0.05\right)$, $20 \mathrm{~cm}\left(\mathrm{Q}_{\text {(Tukey omparison })}=6.28, P<0.05\right)$, and $100 \mathrm{~cm}\left(\mathrm{Q}_{\text {(Tukey omparison })}=4.20, P<0.05\right)$ (Fig. 4A).

40 visits of 1 forager versus 40 visits by 10 foragers. In this test series 10 foragers visited the experimental feeder a total of 40 times. In the choice phase $63.6 \pm 3.4 \%$ of the bees chose the experimental feeder (scented sugar water; $\mathrm{d}=20 \mathrm{~cm}$ ). This percentage did not differ from the results obtained when using a feeder previously visited 40 times by a single forager $(63.8 \pm 5.8 \%$ scented sugar water; $\mathrm{d}=20 \mathrm{~cm}$; Student- $t$-Test, $\mathrm{T}_{10}=0.05, P=0.94$ ).

Number of visits necessary to effectively mark a feeder. The proportions of bees choosing the experimental feeders in the choice phase of this experimental series differed significantly from those of the control group (one-way ANOVA, $\left.\mathrm{F}_{5,30}=14.46, P<0.001\right)$. A significantly larger proportion of bees chose the experimental feeder only after 40,100, and 200 forager visits (one-way ANOVA, Tukey comparison: $\mathrm{Q}_{(20 \text {-control })}=0.87, P>0.05$; 
$\mathrm{Q}_{(30 \text {-control })}=2.46, P>0.05 ; \mathrm{Q}_{(40 \text {-control })}=$ 8.87, $P<0.05 ; \mathrm{Q}_{(100 \text {-control })}=6.75, P<0.05$; $\left.\mathrm{Q}_{(200 \text {-control })}=6.75, P<0.05\right)$ (Fig. 4B).

Persistence of scent marks. 10 foragers fed on an experimental feeder for 10 minutes $(89.3 \pm$ 6.6 visits, 30 experiments). Afterwards, the effect of their scent marks decreased with time (linear regression, $\mathrm{R}^{2}=0.40, \mathrm{~b}=-0.08$ ). Taking the mean percentage of bees landing at the experimental feeder as a measure of the persistence of the scent marks' effect, a significant difference from the control group was found for scent marks that had been stored away (see Methods) for different periods of time (up to 120 minutes) (one-way ANOVA, $\mathrm{F}_{5,30}=5.22$, $P<0.05$; Tukey comparison: $\mathrm{Q}_{(30 ' \text {-control })}=$ 5.86, $P<0.05 ; \mathrm{Q}_{(60 ' \text {-control })}=4.70, P<0.05$; $\mathrm{Q}_{(120 ' \text {-control })}=3.95, P<0.05 ; \mathrm{Q}_{(180 ' \text {-control })}=$ $\left.2.37, P>0.05 ; \mathrm{Q}_{(240 ' \text {-control })}=0.75, P>0.05\right)$ (Fig. 4C).

\section{DISCUSSION}

\subsection{Scent marking at the food source}

Attractant scent marks left at the food source have already been described for different genera of stingless bees (Trigona: Villa and Weiss, 1990; Scaptotrigona: Schmidt et al., 2003; Melipona: Nieh, 1998; Aguilar and Sommeijer, 2001; Jarau et al., 2002). Scaptotrigona aff. depilis, a scent trail laying species, uses two different scent marking systems: The scent trail which guides recruits to a food source, and a scent beacon at the food source itself which indicates the endpoint of the search (Schmidt et al., 2003). Melipona species do not use scent trails (Lindauer and Kerr, 1958; Nieh and Roubik, 1996; Hrncir et al., 2000). However, they do deposit scent marks at the food source thereby helping other bees to find it.

The present study suggests the following scent marking system in $M$. seminigra. Scent left at the food source accumulates with the number of bee visits. It needs about 40 visits for the scent to reach an effective concentration (Fig. 4B). The scent marks remain effective for up to at least two hours, but their effect decreases with time (Fig. 4C). Our findings are strongly reminescent of the situation described for Apis mellifera (Butler et al., 1969), where the attractivity of "footprint substances", used for nest entrance marking, increases with the number of the "footprints" up to a saturation level and persists for up to four hours. In contrast to the assumptions and findings of Nieh (1998) for M. panamica, the effect of the scent marks of $M$. seminigra is affected by the scent of the food proper. In both cases, when using scented or unscented sugar water, the scent marks are most effective at feeder - control feeder distances $d$ between $20 \mathrm{~cm}$ and $1 \mathrm{~m}$. Yet the proportion of bees choosing a scent marked feeder is significantly higher when the food itself is not scented by the experimenter and does not interfere with the scent marks deposited on the feeder by the bees (Fig. 4A).

\subsection{The importance of footprints}

In $M$. seminigra the scent marks are not deposited into the sugar water itself during the ingestion of food (Fig. 2A), nor do abdominal droplets alone attract foragers (which themselves had deposited them) or other bees (Fig. 2B). Both "used" sugar water and abdominal droplets had no repellent effect on searching bees either. Feeders baited with one of these two substances attracted a proportion of bees equal to that attracted by a simultaneously offered clean feeder (Fig. 2). In this regard, $M$. panamica behaves similarly (Nieh, 1998). In contrast, in M. favosa collecting bees significantly preferred a feeder baited with abdominal droplets (Aguilar and Sommeijer, 2001). It was suggested that abdominal droplets help the bees depositing them to find a food source ("self-communication hypothesis"). However, other possible scent marks like footprint substances which the bees might have left at the food source were not excluded in this study.

By covering the tarsi and pretarsi with nail polish we could eliminate the scent marking effect in M. seminigra. The bees thus treated could still deposit abdominal droplets and other potential marking substances such as secretions of their mandibular or labial glands. Even after 80 forager visits, however, bees were unable to distinguish between the experimental- and the control feeder (Fig. 3A). These findings not only confirm the lack of a scent marking effect of the abdominal droplets but also exclude the mandibular and labial 
glands as sources of the scent marks in the context studied. Instead they point to the importance of "footprints".

The footprint substances used for scent marking are not on the bees' general leg cuticle (Fig. 3B) nor are they taken up with the bees' legs from other body parts during movements like autogrooming, or leg rubbing as described by Kerr and Rocha (1988) and Kerr (1994). On the other hand, the effect of tarsal extracts was similar to that of the scent marks deposited by the foragers (Fig. 3B). Our results therefore strongly suggest that the source of the scent marks are glands situated within the bees' legs, and that the scent mark substances are released distally on the legs. The treatment with nail polish most probably sealed the openings of the secretory canals at the base of the pretarsi (Salles and da Cruz-Landim, 1998).

When foraging, stingless bees of the genus Melipona were found to at least initially search randomly for a food source (Jarau et al., 2000, 2003). Any supplementary hint at the food source, such as the scent marks described here, is likely to help the recruits in finding the goal of their search.

Footprint substances are used to mark food sources by other bees as well. The available studies on how they effect the foragers are ambiguous, however. Tarsal gland secretions left by bumblebees at a food source repel both conspecifics and bees of other species, including honeybees (Stout et al., 1998; Goulson et al., 2000; Stout and Goulson, 2001). Their repellent effect decreases with time (Stout and Goulson, 2001) and with decreasing concentration (Goulson et al., 2000). In laboratory experiments, on the other hand, tarsal secretions attracted bumblebees to food sources (Schmitt and Bertsch, 1990; Schmitt et al., 1991). Honeybees use footprint substances to mark the entrance of their nest (Butler et al., 1969). There is no evidence yet that these substances are also deposited at food sources (Stout and Goulson, 2001).

\section{ACKNOWLEDGEMENTS}

We thank Sidnei Mateus for his unfailing help with the maintenance of the bee colonies, and Manfred Ayasse for valuable discussions and suggestions. This work complies with the current
Brazilian laws and was supported by grant P14328 of the Austrian Science Foundation (FWF) to FGB.

Résumé - Origine et propriétés des marques odorantes déposées à la source de nourriture par une abeille sans aiguillon, Melipona seminigra. Le marquage odorant des sources de nourriture augmente l'efficacité de butinage des abeilles sociales. La présence d'attractifs à la source de nourriture est déjà connue chez les abeilles mellifères, les bourdons et certains genres d'abeilles sans aiguillon (Trigona, Scaptotrigona et Melipona). Chez Trigona et Scaptotrigona un chemin odorant guide les recrues du nid à la source de nourriture, qui est elle-même marquée par une autre odeur. Les abeilles du genre Melipona n'utilisent pas de chemin odorant, mais seulement le marquage odorant de la source de nourriture. On connaît peu de choses concernant les propriétés de ces marques odorantes et les études sur leur origine sont sujettes à controverse. Jusqu'à présent on a supposé que « l'odeur de la ruche » et les gouttelettes abdominales déposées par les abeilles à la source de nourriture et dans ses alentours servaient de marques odorantes. Le but de cette étude était de déterminer l'origine et les propriétés des marques odorantes déposées par les butineuses de Melipona seminigra Friese 1903 à la source de nourriture. Les abeilles avaient à choisir entre un nourrisseur marqué par une odeur et un nourrisseur test (Fig. 1).

Ni le sirop « usé » (que les abeilles avaient précédemment utilisé pour se nourrir), ni les gouttelettes abdominales n'ont attiré les abeilles (Figs. 2A, 2B). On a empêché le marquage odorant en couvrant les tarses et prétarses des abeilles de vernis à ongles. Même après 80 visites de butineuses traitées ainsi, les abeilles suivantes étaient incapables de discriminer les deux nourrisseurs. Ces résultats montrent l'importance des «empreintes de pieds » dans le processus de marquage odorant. Pour pousser plus loin le test, les abeilles devaient choisir entre un nourrisseur amorcé avec des extraits de tarsomères et un témoin. Les extraits ont attiré les abeilles aussi fortement que l'odeur déposée naturellement par les butineuses (Fig. 3B). Nous concluons que chez M. seminigra les marques odorantes présentes à la source de nourriture proviennent des glandes situées à l'extrémité de la patte. Selon les expériences portant sur diverses distances entre le nourrisseur testé et le témoin, les marques odorantes de $M$. seminigra ont un rayon d'action d'environ $1 \mathrm{~m}$ (Fig. 4A). Il faut environ 40 visites à la source de nourriture pour que le marquage odorant soit effectif (Fig. 4B). Nos expériences montrent en outre que les marques odorantes restent attractives pendant 2 h (Fig. 4C).

Melipona / abeille sans aiguillon / marquage odorant / substance d'empreinte de pied / recrutement 
Zusammenfassung - Über Herkunft und Eigenschaften von an der Futterquelle abgesetzten Duftmarken bei einer stachellosen Biene (Melipona seminigra). Soziale Bienen können Futterquellen effizienter ausbeuten, wenn sie diese chemisch markieren. Anlockende Duftsignale an Futterquellen wurden bereits bei Apis, Bombus und einigen Gattungen stachelloser Bienen (Trigona, Scaptotrigona, Melipona) nachgewiesen. Bei Trigona und Scaptotrigona spielen Duftsignale eine besonders wichtige Rolle: Die Rekruten folgen einem von Sammelbienen gelegten Duftpfad zur Futterquelle, die selbst durch ein weiteres, unterschiedliches Duftsignal markiert ist. Bienen der Gattung Melipona verwenden keine Duftpfade, um Rekruten zu einer Futterquelle zu leiten, setzen jedoch ein anlockendes Duftsignal an der Futterquelle selbst $a b$. Über dessen Eigenschaften ist bisher wenig bekannt, und die vorliegenden Daten zu seiner Herkunft sind widersprüchlich. Einerseits soll ein „Stockgeruch“, andererseits sollen von den Bienen abgesetzte „Analtröpfchen“ anlockende Wirkung haben.

Das Ziel unserer Untersuchung war es, die Herkunft und die Eigenschaften von Duftsignalen zu ermitteln, die von Melipona seminigra Friese 1903 an der Futterquelle abgesetzt werden. In Wahlexperimenten mussten sich Bienen zwischen einer Futterquelle, die zuvor von Sammelbienen besucht worden war, und einer Kontroll-Futterquelle entscheiden (Abb. 1). Um die Herkunft der Duftsignale zu ermitteln, wurde zunächst untersucht, ob Sammelbienen die Zuckerlösung selbst beduften und die abgesetzten Analtröpfchen einen Effekt auf das Wahlverhalten der Bienen haben.

Weder das „gebrauchte“ Zuckerwasser noch die Analtröpfchen wirkten anlockend auf die Bienen (Abb. 2A, 2B). Hingegen zeigte sich die Wichtigkeit der „Fußabdrücke“ (,footprints“) für das Markieren einer Futterquelle dadurch, dass durch Überlackieren der Tarsen und Praetarsen das Duftmarkieren ausgeschaltet werden konnte (Abb. 3A). Versuche, bei denen sich Bienen zwischen einer mit Tarsalextrakten versehenen Futterquelle und einer Kontroll-Futterquelle entscheiden mussten, bestätigten diese Interpretation. Die Extrakte hatten die gleiche anlockende Wirkung wie die während des natürlichen Sammelprozesses abgesetzten Duftmarken (Abb. 3B). Daraus ist zu schließen, dass Substanzen zur Markierung von Futterquellen aus Drüsen in den Beinen stammen und an den Tarsen oder Praetarsen abgegeben werden.

Durch Variation des Abstands zwischen der experimentellen und der Kontroll-Futterquelle sowie der Anzahl der vorangegangenen Besuche von Sammelbienen ließ sich zeigen, dass die Duftsignale von $M$. seminigra in einem Umkreis von bis zu etwa $1 \mathrm{~m}$ wirksam sind (Abb. 4A) und eine Futterquelle zumindest 40 mal besucht werden muss, bis sich die anlockende Wirkung des Duftsignals nachweisen lässt (Abb. 4B). Die
Duftmarken verlieren nach etwa 2 Stunden ihre Wirkung (Abb. 4C).

\section{Melipona / stachellose Biene / Fußabdrücke / Duftpfade / Rekrutierung}

\section{REFERENCES}

Aguilar I., Sommeijer M. (1996) Communication in stingless bees: Are the anal substances deposited by Melipona favosa scent marks? Proc. Exp. Appl. Entomol., N.E.V. Amsterdam 7, 56-63.

Aguilar I., Sommeijer M. (2001) The deposition of anal excretions by Melipona favosa foragers (Apidae: Meliponinae): behavioural observations concerning the location of food sources, Apidologie 32, 37-48.

Ayasse M., Engels W., Lübke G., Francke W. (1999) Mating expenditures reducedvia female sex pheromone modulation in the primitively eusocial halictine bee, Lasioglossum (Evylaeus) malachurum (Hymenoptera: Haltictidae), Behav. Ecol. Sociobiol. 45, 95-106.

Butler C.G., Fletcher D.J.C., Watler D. (1969) Nestentrance marking with pheromones by the honeybee, Apis mellifera L., and by the wasp, Vespula vulgaris L., Anim. Behav. 17, 142-147.

Cameron S.A. (1981) Chemical signals in bumble bee foraging, Behav. Ecol. Sociobiol. 9, 257-260.

Corbet S.A., Kerslake C.J.C., Brown D., Morland N.E. (1984) Can bees select nectar-rich flowers in a patch? J. Apic. Res. 23, 234-242.

Ferguson A.W., Free J.B. (1979) Production of a forage-marking pheromone by the honeybee, $\mathrm{J}$. Apic. Res. 18, 128-135.

Free J.B., Williams I.H. (1983) Scent marking of flowers by bumblebees, J. Apic. Res. 22, 86-90.

Free J.B., Williams I.H., Picket J.A., Ferguson A.W., Martin A.P. (1982) Attractiveness of (Z)-11eicosen-1-ol to foraging honeybees, J. Apic. Res. $21,151-156$

Giurfa M. (1993) The repellent scent-mark of the honeybee Apis mellifra ligustica and its role as communication cue during foraging, Insectes Soc. 40, 59-67.

Giurfa M., Nuñez J.A. (1992) Honeybees mark with scent and reject recently visited flowers, Oecologia 89, 113-117.

Golub M.A., Weatherston I. (1984) Techniques for extracting and collecting sex pheromones from live insects and from artificial sources, in: Hummel H.E., Miller T.A. (Eds.), Techniques in Pheromone Research, Springer, New York, pp. 223-285.

Goulson D., Hawson S.A., Stout J.C. (1998) Foraging bumblebees avoid flowers already visited by conspecifics or by other bumblebee species, Anim. Behav. 55, 199-206.

Goulson D., Stout J.C., Langley J., Hughes W.O.H. (2000) Identity and function of scent marks 
deposited by foraging bumblebees, J. Chem. Ecol. 26, 2897-2911.

Goulson D., Chapman J.W., Hughes W.O.H. (2001) Discrimination of unrewarding flowers by bees; direct detection of rewards and use of repellent scent marks, J. Insect Behav. 14, 669-678.

Hrncir M., Jarau S., Zucchi R., Barth F.G. (2000) Recruitment behavior in stingless bees, Melipona scutellaris and Melipona quadrifasciata. II. Possible mechanisms of communication, Apidologie 31, 93-113.

Jarau S., Hrncir M., Zucchi R., Barth F.G. (2000) Recruitment behavior in stingless bees, Melipona scutellaris and Melipona quadrifasciata. I. Foraging at food sources differing in direction and distance, Apidologie 31, 81-91.

Jarau S., Hrncir M., Zucchi R., Barth F.G. (2002) Footprint pheromones used to mark food sources by stingless bees, XIV International Congress of IUSSI, Hokkaido University, Sapporo, Japan, p. 16.

Jarau S., Hrncir M., Schmidt V.M., Zucchi R., Barth F.G. (2003) Effectiveness of recruitment behavior in stingless bees (Apidae, Meliponini), Insectes Soc. 50, 365-374.

Kato M. (1988) Bumblebee visits to Impatiens spp.: pattern and efficiency, Oecologia 76, 364-370.

Kerr W.E. (1994) Communication among Melipona workers (Hymenoptera: Apidae), J. Insect Behav. 7, 123-128.

Kerr W.E., Esch H. (1965) Communicação entre as abelhas sociais brasileiras e sua contribuição para o entendimento da sua evolução, Ciênc. Cult. 17, 529-538.

Kerr W.E., Rocha R. (1988) Communicação em Melipona rufiventris e Melipona compressipes, Ciênc. Cult. 40, 1200-1202.

Kerr W.E., Ferreira A., Mattos N.S. (1963) Communication among stingless bees - additional data (Hymenoptera: Apidae), J. N.Y. Entomol. Soc. 71, 80-90.

Kerr W.E., Blum M., Fales H.M. (1981) Communication of food sources between workers of Trigona (Trigona) spinipes, Rev. Bras. Biol. 41, 619-623.

Lindauer M., Kerr W.E. (1958) Die gegenseitige Verständigung bei den stachellosen Bienen, Z. Vgl. Physiol. 41, 405-434.

Nieh J.C. (1998) The role of a scent beacon in the communication of food location by the stingless bee, Melipona panamica, Behav. Ecol. Sociobiol. 43, 47-58.

Nieh J.C., Roubik D.W. (1995) A stingless bee (Melipona panamica) indicates food location without using a scent trail, Behav. Ecol. Sociobiol. 37, 63-70.

Nuñez J.A. (1967) Sammelbienen markieren versiegende Futterquellen durch Duft, Naturwissenschaften 54, 322-323.

Salles H.C., Cruz-Landim C. da (1998) Levantamento das glândulas exócrinas presentes em Camargoia nordestina Moure, 1989 (Hymenoptera, Apidae, Meliponinae), Rev. Bras. Entomol. 41, 297-302.

Schmidt V.M., Zucchi R., Barth F.G. (2003) A stingless bee marks the feeding site in addition to the scent path (Scaptotrigona aff. depilis Moure 1942), Apidologie 34, 237-248.

Schmitt U., Bertsch A. (1990) Do foraging bumblebees scent-mark a food source and does it matter? Oecologia 82, 137-144.

Schmitt U., Lübke G., Francke W. (1991) Tarsal secretion marks food sources in bumblebees (Hymenoptera: Apidae), Chemoecology 2, 3540.

Sokal R.R., Rohlf F.J. (1995) Biometry, 3rd ed., Freeman, New York.

Stout J.C., Goulson D. (2001) The use of conspecific and interspecific scent marks by foraging bumblebees and honeybees, Anim. Behav. 62, 183-189.

Stout J.C., Goulson D., Allen J.A. (1998) Repellent scent-marking of flowers by a guild of foraging bumblebees (Bombus spp.), Behav. Ecol. Sociobiol. 43, 317-326.

Vallet A., Cassier P., Lensky Y. (1991) Ontogeny of the fine structure of the mandibular glands of the honeybee (Apis mellifera L.) workers and the pheromonal activity of 2-heptanone, J. Insect Physiol. 37, 789-804.

Villa J.D., Weiss M.R. (1990) Observations of the use of visual and olfactory cues by Trigona spp. foragers, Apidologie 21, 541-545.

Weatherwax P.B. (1986) Why do honeybees reject certain flowers? Oecologia 69, 567-570.

Winston M.L. (1987) The Biology of the Honey Bee, Harvard University Press, Cambridge.

Williams C.S. (1998) The identity of the previous visitor influences flower rejection by nectarcollecting bees, Anim. Behav. 56, 673-681. 